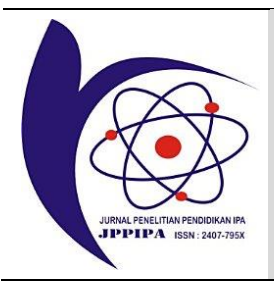

\title{
Students' Conceptual Understanding through Implementation of LiveWire in Basic Electronics Virtual Experiment
}

\author{
Muh. Makhrus ${ }^{1 *}$, Wahyudi' ${ }^{1}$, Muhammad Zuhdi ${ }^{1}$ \\ ${ }^{1}$ Physics Education, Faculty of Teacher Training and Education, University of Mataram, Indonesia
}

DOI: $10.29303 /$ jppipa.v7i2.705

\section{Article Info}

Received : February 27th, 2021

Revised : April 15th, 2021

Accepted: April 19th, 2021

\begin{abstract}
As a result of Covid-19, the learning system has changed towards online learning. Practicum activities encountered obstacles and had to be replaced by virtual experiments. This study aims to see the role of virtual experiments during online learning in basic electronics courses and to describe students' conceptual understanding. The subject in this study amounted to 56 students. The research data collection instrument used a conceptual understanding test. Data were analyzed by descriptive statistics. This virtual experiment using the LiveWire application. The results showed that virtual experiments carried out during online learning were able to help students' practicum activities and most students had a high category understanding of concepts after learning. This shows that virtual experiments with LiveWire can be used as an alternative to assist practicum activities when doing online learning.
\end{abstract}

Keywords: Conceptual Understanding Basic electronics; Virtual Experiment; Online Learning; LiveWire application.

Citation: $\quad$ Makhrus, M., Wahyudi, W., \& Zuhdi, M. (2021). Students' Conceptual Understanding through Implementation of LiveWire in Basic Electronics Virtual Experiment. Jurnal Penelitian Pendidikan IPA, 7(2), 249-254. doi:https://doi.org/10.29303/jppipa.v7i2.705

\section{Introduction}

Science helps an individual to survive in an increasingly changing scientific and technological world. That is, peoples need to apply scientific thinking in all parts of their lives. Physics is one of the clumps in science which is closely related to everyday life. Physics is a science that studies natural phenomena and their symptoms (Sari, et al., 2017). Physics topics previously studied significantly influence students' conceptual understanding (Chu, et al., 2012). Each student's ability to understand concepts is different. Some students have an understanding that is in accordance with the principles and theories in physics, but many also have an incompatible understanding.

Understanding the concept is an important initial part of learning, especially physics. Physics is a field in science that prioritizes understanding concepts rather than just remembering (Diani, et al., 2018). Understanding the concept is likened to a foundation for gaining problem-solving, creative thinking, and critical thinking skills. Conceptual understanding is the process of acting to properly understand a design or an abstract idea that allows a person to classify an object or event, and understanding the concept is obtained through the learning process (Alatas, 2015). Physics lessons have many abstract concepts. Some physics concepts need to be taught experimentally to be able to visualize these concepts. Conceptual understanding is not just a simple understanding, but can also be described as the ability to understand, understand, apply, classify, generalize, synthesize and conclude objects. Conceptual understanding is the ability to understand a concept and interpret a material well. Furthermore, understanding the concept is an ability that not only understands but can also connect initial knowledge with new knowledge 
so that it gives birth to knowledge products including principles, laws, and theories (Yulisa, et al., 2020). However, some problems often occur related to students' understanding of concepts such as still allowing students to experience misconceptions and low understanding of concepts. The low understanding of students concepts can be caused by several factors including students' lack of interest in learning the material and the media used do not make students interested in learning (Yulisa et al., 2020). When students' conceptual understanding is good, students have the opportunity to improve their thinking skills and help them to understand the next material (Fratiwi, et al., 2018).

As online learning takes effect as a result of the spread of the COVID-19 disease, direct learning (face-toface) are not possible. Online learning or so-called Elearning is a learning system that utilizes information and communication technology in learning activities. Google classroom, google meet, zoom meeting, Edmodo, and various LMS (Learning Management System) are examples of online learning platforms (Setiaji \& Dinata, 2020). Online learning is learning when students and teachers are not always physically present at school (Setiawan, 2020). Along with technological developments, online learning has become common in this era. Adjustments to the teaching methodology need to be continuously studied and improved, through the available tools and platforms (Basilaia \& Kvavadze, 2020). Online learning (E-Learning) is a learning system that utilizes information and communication technology facilities using online media, to continue the learning process even without meeting face to face at school (Pakpahan \& Fitriani, 2020).

Virtual experiments are alternative experiments in this online learning period. Virtual experiments provide an overview of physics concepts that are difficult to observe directly, this makes learning interesting, and students can manipulate several complex phenomena (Billah \& Widyatmoko, 2018). Virtual experiments can be defined as a series of computer programs that can visualize abstract phenomena or complex experiments carried out in real laboratories, to increase learning activities to develop skills needed in problem-solving (Yusuf \& Subaer, 2013). The virtual experiment provides a visual or an explanation of a situation via computer simulation. Students have the opportunity to interact to respond to these circumstances. Virtual media experiments are experiments using virtual media such as computer simulations or laboratory media virtual (Makhrus, et al. ,2020). The advantage of virtual laboratories is that they can explain abstract concepts that cannot be explained through verbal delivery (Saputra, et al., 2017) and virtual experiments are alternative solutions for damaged laboratory equipment (Fiscarelli, et al., 2013). The purpose of using virtual laboratory-based media is to make it easier to communicate and build concepts about abstract physics material content (Saregar, 2016).

One of the virtual experimental media that can be used to assist the learning process is the LiveWire application. The use of the LiveWire program can make it easy for students to understand the basic competencies of electrical and electronic theory as well as ease in the application of learning materials for Ohm's Law and Kirchoff's Law. This LiveWire application allows students to explore material through virtual experiments (Zulfa, et al., 2019). One of the subjects that require practicum activities is basic electronics. This subject requires experimental activities to make students understand the material. However, because online learning, the experimental activities are carried out with virtual experiments using the LiveWire application. The purpose of this study was to determine the level of conceptual understanding of students' after implementing online learning with virtual experiments.

\section{Method}

This type of research is using a quantitative approach. This research is a pre-experiment with a oneshot case study design (Table 1). The purpose of this study was to determine the conceptual understanding of students in online learning assisted with virtual experiments. The subjects in this study were students of physics education at the University of Mataram who were taking basic electronics courses, totaling 56 students. Online learning was carried out using SPADA UNRAM and virtual experiments were carried out using the LiveWire application.

Table 1. Research Design

\begin{tabular}{lll}
\hline No & Treatment & Posttest \\
\hline 1 & $\mathrm{X}$ & $\mathrm{O}$ \\
\hline
\end{tabular}

$X$ is online learning assisted with virtual experiment using LiveWire application and $\mathrm{O}$ is the posttest with questionnaire related to practicality and essay test related to conceptual understanding. The practicality of online learning is obtained through a questionnaire instrument while conceptual understanding is obtained using a test. Students' conceptual understanding is categorized as in Table 2 below. The conceptual understanding test consists of 5 essay tests. Indicators of conceptual understanding in this study are: 1) interpreting; 2) classifying; 3) inference; 4) comparing; and 5) explaining. 
Table 2. Categories of Concept Understanding

\begin{tabular}{lll}
\hline No. & Conceptual Understanding Score & Category \\
\hline 1. & $80<$ Score $\leq 100$ & Very High \\
2. & $60<$ Score $\leq 80$ & High \\
3. & $40<$ Score $\leq 60$ & Moderate \\
4. & $20<$ Score $\leq 40$ & Low \\
5. & $0 \leq$ Score $\leq 20$ & Very Low \\
\hline
\end{tabular}

Meanwhile, to determine student responses related to the use of online learning and LiveWire applications as virtual experiments, analysis was carried out using quantitative descriptive. The indicators used in the student response questionnaire include: 1) Ease of use of the LiveWire application, 2) attractiveness of the LiveWire application, and 3) suitability of the theory being studied. Student response analysis aims to describe and determine the level of practicality of online learning with the LiveWire application. Learning that is carried out can be said to have practicality if students more than $75 \%$ respond positively or very positively. The experimental activities are: 1) Thevenin Theorem; 2 ) NPN Transistors; 3) Dioda Rectifier; 4) Light-Dependent Resistor (LDR) circuits; 5) Voltage rectifier circuit with a JFET and MOSFET transistor. This learning was carried out in 5 meetings and posttest. Each meeting carries out virtual experimental activities according to the topic and virtual experiments using the LiveWire application.

\section{Result and Discussion}

Along with the still rapid development of Covid19 which hinders activities in all sectors. The learning system at the University of Mataram experienced the same impact, namely learning activities that were initially face-to-face had to be transferred to the online system. Online learning is carried out through SPADA UNRAM (University of Mataram Online Learning System). However, some courses that require practical activities experience problems with their practicum. This online learning system cannot guarantee that all practicum activities run properly. One of the practicum activities that were affected was the basic electronics practicum which was carried out on physics education students, Faculty of Teacher Training and Education, University of Mataram. To be able to carry out practicum activities, it is done through a virtual practicum with the help of a live wire application. This virtual practicum activity is expected to be an alternative solution for practicum activities when learning that applies the online system. This virtual practicum activity is used to help students fulfill practicum objectives and help them understand the concept. The example of virtual practicum activities is shown in Figure 1.

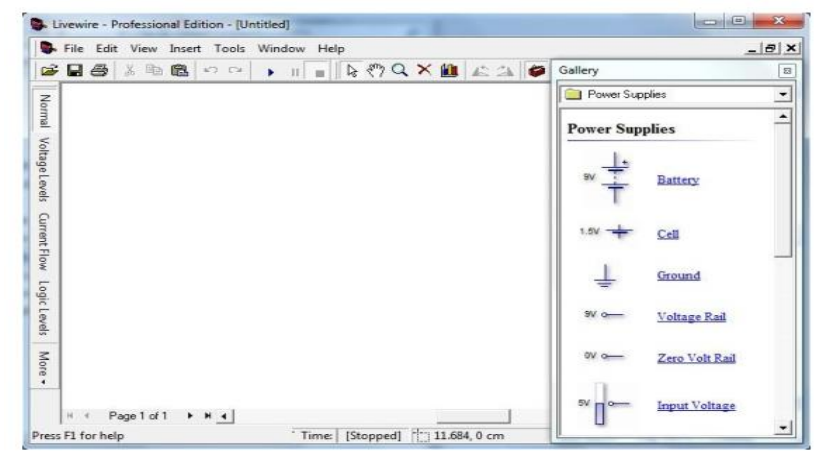

Figure 1. Display LiveWire when operated on computer

This LiveWire application is an alternative to help virtual experiments in basic electronics courses. There are several practical activities carried out with LiveWire. At the first online meeting at SPADA UNRAM, students were asked to carry out virtual practicum activities using LiveWire related to Thevenin theorem. Students are given a practicum module for LiveWire use. The purpose of the virtual practicum at this first meeting was to determine the output voltage and to determine Thevenin resistance using the LiveWire application. The form of the Thevenin circuit with LiveWire is shown in Figure 2.

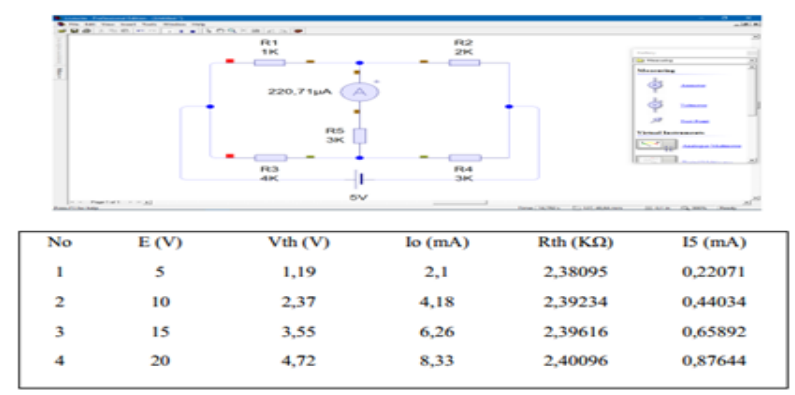

Figure 2. Example of Thevenin Circuit with LiveWire and Result Experiment

Based on the experiment, students know that the greater the value of Thevenin resistance, the greater the value of the voltage drop, and the smaller the value of Thevenin resistance, the smaller the value of the voltage drop. This result is following Thevenin's theory. This shows that virtual experiments with LiveWire can be an alternative to practicum if learning is still running online. Likewise, other experiments are still being carried out using LiveWire. The second experiment was related to the NPN transistor as a switch, the third experiment with a rectifier diode with an oscilloscope (observing the output waveform of a wave rectifier), the fourth experiment with a light-dependent resistor circuit, and the fifth experiment using a voltage rectifier circuit with a JFET and MOSFET transistor. This online practicum continues with directions and assistance from 
the lecturer so that the procedure and results of the experiment are as expected. Based on the results of virtual experiments with LiveWire, the objectives of each experiment can be achieved and according to theory. Students can understand the concept of the experiment being carried out. This helps students understand theories in basic electronics courses. Online learning with virtual experiments is compatible with face-to-face learning with practical laboratory work directly. Online learning with virtual experiments using the LiveWire application has several advantages such as flexibility in conducting experiments and features in the application are easy to understand. The use of LiveWire has a positive effect on students' logical thinking skills (Prasetyono \& Hariyono, 2019).

The use of LiveWire is quite simple and easy to understand for students. After carrying out virtual practicum activities for six times online, students are given a concept understanding test to find out their understanding of the concept after online learning assisted with virtual practicum with LiveWire. The results of students' concept understanding tests are categorized as in Figure 3 below.

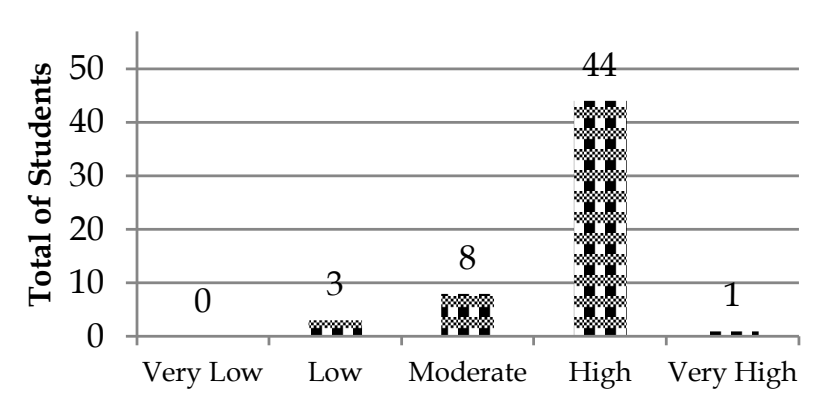

Level of Conceptual Understanding

Figure 3. Level of Conceptual Understanding after Learning

The results of the conceptual understanding test showed that most students had a high category of conceptual understanding. This shows that the use of LiveWire can help practicum activities during online learning and can improve student understanding of concepts. Online learning based on virtual experiments makes it easy for students to understand lessons. The virtual laboratory assisted online learning process that is applied can make students active in the learning process and provide opportunities for students to find information on their own (Dewa, et al., 2020). Virtual experiments can be used as an alternative in learning because they can visualize the actual concept so that there is a change in the concept of students (Makhrus et al., 2020). The LiveWire application can provide a visualization of the direction of electric current passing through conductors or other components. This application can also be used to prove the completion of questions related to the topic of electricity (Wahyudi, et al., 2020). High category students' conceptual understanding shows that they understand the concepts taught and practiced through the LiveWire application. On indicators of interpreting, as many as $82.14 \%$ of high ability students. On the indicators of classifying and comparing, the percentage of highly capable students is around $71.24 \%$ of the total students. In both indicators, there are still quite a lot of students with moderate and low abilities. So that this indicator is more emphasized to be trained again. On the indicator explaining, as many as $89.29 \%$ of high ability students. This shows that most students can explain material or concepts learned in basic electronics courses. In the inference indicator, as many as $78.57 \%$ of high ability students. Based on this, several indicators of conceptual understanding such as classifying, comparing, and inference require more attention and need more training to be maximized. But overall, students' conceptual understanding of online learning assisted by the LiveWire application is high. The percentage of students with high abilities after learning was $78.57 \%$ of the total students. Meanwhile, the percentage of students with low ability was $5.36 \%$, the moderate ability was $14.29 \%$, and $1.79 \%$ was categorized as very high.

Several results of student questionnaire responses related to online learning with virtual experiments gave positive responses. Students said the LiveWire application could be an online practicum solution because it was interesting and easy to understand and could be done independently. As many as $82 \%$ of students responded positively to online learning with this LiveWire application, $14 \%$ responded very positively, and only $4 \%$ responded moderately and less positively (Figure 4). Based on this, online learning with the LiveWire application is also practically used in helping virtual experiments and helping students understand the concepts being taught related to basic electronics.

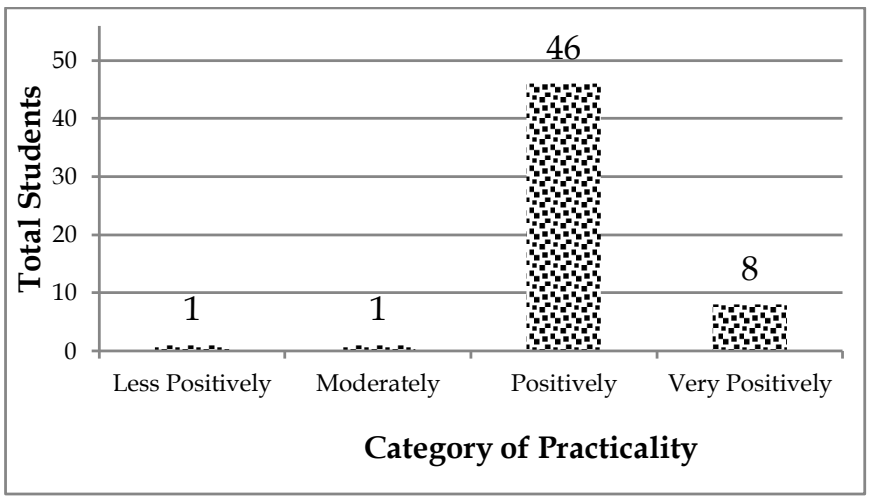

Figure 4. Results of student response questionnaires about practicality 
This practicality and positive response were also supported by the comments of several students regarding online learning with the LiveWire application. Students said that this LiveWire application has simple features so that it is easy to use and understand. In addition, this application is flexible enough to be used in several operating systems. With the help of a module using the LiveWire application, it is easier for students to carry out virtual practicum activities related to basic electronics.

\section{Conclusion}

Most of the students' understanding of basic electronics concepts was in the high category. This proves that online learning assisted by virtual experiments with LiveWire applications can be used as an alternative to practicum activities during online learning. The use of LiveWire is relatively simple and easy for students to understand. However, it needs to be understood that virtual practicum in online learning cannot be applied to all materials. In physics learning, certain materials need more guidance from lecturers to help students understanding. Several indicators of conceptual understanding such as classifying, comparing, and inference need to be trained more actively so that students' understanding of concepts is maximized.

\section{References}

Alatas, F. (2015). Hubungan Pemahaman Konsep Dengan Keterampilan Berpikir Kritis Melalui Model Pembelajaran Treffinger Pada Mata Kuliah Fisika Dasar. Edusains, 6(1), 87-96. https://doi.org/10.15408/es.v6i1.1103 [ndonesian [Indonesian]

Basilaia, G., \& Kvavadze, D. (2020). Transition to Online Education in Schools during a SARS-CoV-2 Coronavirus ( COVID-19) Pandemic in Georgia. Pedagogical Research, 5(4), 1-9. https://doi.org/https://doi.org/10.29333/pr/79 37

Billah, A., \& Widyatmoko, A. (2018). The Development of Virtual Laboratory Learning Media for The Physical Optics Subject. Jurnal Ilmiah Pendidikan Fisika Al-Biruni, 7(2), 153. https://doi.org/10.24042/jipfalbiruni.v7i2.2803

Chu, H., Treagust, D. F., Yeo, S., \& Zadnik, M. (2012). International Journal of Science Evaluation of Students ' Understanding of Thermal Concepts in Everyday Contexts. International Journal of Science Education, 34(10), 1509-1534. https://doi.org/10.1080/09500693.2012.657714
Dewa, E., Mukin, M. U. J., \& Pandango, O. (2020). Pengaruh Pembelajaran Daring Berbantuan Laboratorium Virtual Terhadap Minat dan Hasil Belajar Kognitif Fisika. Jurnal Riset Teknologi Dan Inovasi Pendidikan, 3(2), 351-359. [Indonesian]

Diani, R., Latifah, S., Anggraeni, Y. M., \& Fujiani, D. (2018). Physics Learning Based on Virtual Laboratory to Remediate Misconception in Fluid Material. Tadris: Jurnal Keguruan Dan Ilmu Tarbiyah, 3(2), 167. https://doi.org/10.24042/tadris.v3i2.3321

Fiscarelli, S. H., Bizelli, M. H. S. S., \& Fiscarelli, P. E. (2013). International Journal of Learning Interactive Simulations to Physics Teaching: A Case Study in Brazilian. International Journal of Learning and Teaching, 5(1), 18-23.

Fratiwi, N. J., Samsudin, A., \& Costu, B. (2018). Enhancing K-10 Students' Conceptions Through Computer Simulations-Aided PDEODE*E (CSPDEODE*E) On Newton's Laws. Jurnal Pendidikan IPA Indonesia, 7(2), 214-223. https://doi.org/10.15294/jpii.v7i2.14229

Makhrus, M., Ayub, S., Wahyudi, Verawati, N. N. P. S., \& Busyairi, A. (2020). Kemampuan Berpikir Kritis Mahasiswa pada Materi Optik Saat Proses Pembelajaran dengan CCM-CCA Berbantuan Eksperimen Virtual. Kappa Journal, 4(2), 143-148. [Indonesian]

Pakpahan, R., \& Fitriani, Y. (2020). Analisa Pemanfaatan Teknologi Informasi dalam Pembelajaran Jarak Jauh di Tengah Pandemi Virus Corona COVID-19. JISAMAR: Journal of Information System, Applied, Management, Accounting and Researh, 4(2), 30-36. [Indonesian]

Prasetyono, R. N., \& Hariyono, R. C. S. (2019). Pengaruh Flipbook Gerbang Logika Dengan Menggunakan Livewire Terhadap Kemampuan Berpikir Logis Mahasiswa Teknik Informatika. Joined Journal (Journal of Informatics Education), 2(2), 50-62. [Indonesian]

Saputra, T. B. R. E., Nur, M., \& Purnomo, T. (2017). Pengembangan Pembelajaran Inkuiri Berbantuan Phet Untuk Melatihkan Keterampilan Proses Sains Siswa. Journal of Science Education And Practice, 1(1), 20-31. [Indonesian]

Saregar, A. (2016). Pembelajaran Pengantar Fisika Kuantum dengan Memanfaatkan Media Phet Simulation dan LKM Melalui Pendekatan Saintifik: Dampak pada Minat dan Penguasaan Konsep Mahasiswa. Jurnal Ilmiah Pendidikan Fisika AlBiruni, 5(1), 53. https://doi.org/10.24042/jpifalbiruni.v5i1.105

Sari, W. P., Suyanto, E., \& Suana, W. (2017). Analisis Pemahaman Konsep Vektor pada Siswa Sekolah Menengah Atas. Jurnal Ilmiah Pendidikan Fisika Al- 
Biruni,

$6(2)$,

159.

https://doi.org/10.24042/jipfalbiruni.v6i2.1743

[Indonesian]

Setiaji, B., \& Dinata, P. A. C. (2020). Analisis Kesiapan Mahasiswa Jurusan Pendidikan Fisika Menggunakan e-learning dalam Situasi Pandemi Covid-19. Jurnal Inovasi Pendidikan IPA, 6(1), 59-70. https://doi.org/https://doi.org/10.21831/jipi.v6 i1.31562 [Indonesian]

Setiawan, A. R. (2020). Lembar Kegiatan Literasi Saintifik untuk Pembelajaran Jarak Jauh Topik Penyakit Coronavirus 2019 (COVID-19). Jurnal Edukatif, 2(1), 28-37. [Indonesian]

Wahyudi, Makhrus, M., Gunada, I. W., \& Taufik, M. (2020). Pelatihan Animasi Rangkaian Listrik Menggunakan Live Wire 1 . 11 Pro Bagi Siswa Kelas XII IPA 2 SMA Negeri 7 Mataram. Jurnal PEPADU, 1(2), 179-184. [Indonesian]

Yulisa, Akim, L., \& Lia, L. (2020). Pengaruh Video Pembelajaran Fisika Terhadap Pemahaman Konsep Siswa SMP. Jurnal Luminous: Riset Ilmiah Pendidikan Fisika, 1(1), 37-44. [Indonesian]

Yusuf, I., \& Subaer. (2013). Pengembangan perangkat pembelajaran fisika berbasis media laboratorium virtual pada materi dualisme gelombang partikel di sma tut wuri handayani Makassar. Jurnal Pendidikan IPA Indonesia, 2(2), 189-194. https://doi.org/10.15294/jpii.v2i2.2722 [Indonesian]

Zulfa, A., Supriyati, Y., \& Rustana, C. E. (2019). Pengembangan Lembar Kerja Siswa (Lks) Berbasis Inkuiri Terbimbing Dengan Menggunakan Simulasi Virtual Dari Aplikasi Livewire Pada Materi Arus Searah ( Dc ) Untuk Sma Kelas Xii. Prosiding Seminar Nasional Fisika (E-Journal), VIII, 239-246. [Indonesian] 